Research Article

\title{
A Comparison between the Level of Interleukin 10 (IL-10) in Aterm and Preterm Labor
}

\author{
Perbandingan Kadar Interleukin 10 (IL-10) pada \\ Persalinan Aterm dan Persalinan Preterm
}

\author{
Yusri Lisangan, St. Maisuri T. Chalid, David Lotisna \\ Department of Obstetrics and Gynecology \\ Faculty of Medicine University of Hasanuddin/ \\ Dr. Wahidin Sudirohusodo Hospital \\ Makassar
}

\begin{abstract}
Objective: To compare the level of interleukin 10 in aterm and preterm labor.

Method: The research was conducted from November 1st 2011 until January $31^{\text {st }} 2012$. The subjects were pregnant women underwent labor during the period who had agreed to participate in this study. The study was conducted in the Obstetrics and Gynecology departments of several teaching hospitals of Hasanuddin University in Makassar. The study design was cross sectional with 48 samples. The data were analysed by using the Mann Whithney test.

Results: The result revealed that there was an increase of interleukin 10 level in mothers with preterm labor, in comparison with the control group $(\mathrm{p}<0.05)$.

Conclusion: The level of interleukin 10 in mothers with preterm labor are higher than aterm labors less than espective.

[Indones J Obstet Gynecol 2012; 36-4: 163-6]

Keywords: interleukin 10, preterm labor

Abstrak

Tujuan: Membandingkan kadar interleukin 10 pada persalinan aterm dan persalinan preterm.

Metode: Penelitian ini dilaksanakan sejak 1 November 2011 sampai dengan 31 Januari 2012 terhadap wanita yang sedang dalam persalinan dalam periode penelitian dan setuju untuk berpartisipasi di beberapa rumah sakit pendidikan di Bagian Obstetri dan Ginekologi Fakultas Kedokteran Universitas Hasanuddin Makassar. Penelitian ini merupakan penelitian dengan desain cross sectional study. Jumlah sampel sebanyak 48 orang dengan rincian 12 kasus persalinan preterm dan 36 kontrol pasien persalinan aterm. Analisis data menggunakan uji Mann Whitney.

Hasil: Hasil penelitian menunjukkan peningkatan kadar Interleukin 10 pada ibu dengan persalinan preterm dibandingkan dengan kontrol $(p<0,05)$.

Kesimpulan: Kadar IL-10 serviks pada persalinan prematur lebih tinggi dibandingkan dengan pada persalinan aterm.

[Maj Obstet Ginekol Indones 2012; 36-4: 163-6]

Kata kunci: interleukin 10, persalinan preterm
\end{abstract}

Correspondence: Yusri Lisangan. Jln. Veteran Utara No. 180, Makassar. Telephone: 0811467989. email: yusril_02@yahoo.com

\section{INTRODUCTION}

In the recent years, preterm delivery has become the main attention in obstetric, due to its relation with perinatal morbidity and mortality. In the USA, the incidence of preterm delivery ranged about 6$10 \%{ }^{1}$ In $2002,11.9 \%$ of all birth and $10.4 \%$ from all singleton pregnancy were preterm deliveries, a $7 \%$ raise since $1990 .{ }^{2}$ In the Southeast Asia, there were approximately 3 million cases of preterm deliveries, $10 \%$ of which was in Indonesia. Preterm delivery correlate with $70 \%$ of perinatal mortality and over $75 \%$ of perinatal morbidity. Data from Dr. Cipto Mangunkusumo Hospital in 1986 showed that the incidence of perinatal mortality was 70 out of 1,000 live birth, and $73 \%$ of them were caused by prematurity. In Kariadi Hospital (1995) the incidence of perinatal mortality was 44.7 out of 1000 live birth, and the leading cause (40\%) was prematurity. In 1997, the incidence of perinatal mortality in Indoneisa was 52.2 out of 1,000 live births and the leading cause was preterm delivery. In Wahidin Sudirohusodo Hospital, Makassar, in 2010, 2.75\% of all deliveries were preterm. ${ }^{3}$

The exact cause of preterm delivery is yet to be determined. But there were several conditions considered to be the risk factors of preterm delivery, such as premature rupture of membrane (PROM), amniotic fluid infection, prior history of preterm delivery or abortion, overdistended uterus, fetal death, cervical incompetence, uterus abnormalities, 
IUD retention, maternal medical condition, elective induction and several other unknown factors. ${ }^{1}$

There are still various issues that were not clear, especially the mechanism of preterm delivery from the immunology point of view. Fetus is a foreign paternal antigen, thus there is supposed to be some kind of rejection reaction. There has been several theory made to explain this phenomenone, such as the theory of fetus as an allograft, or that the placenta is a immunology barrier for the fetus. ${ }^{4}$

Recenlty, it was predicted that there was a correlation between preterm delivery and chorioamnionitis, which is an invasion of bacteria of micoplasma in the amniotic fluid or embrane. Eventhough the incidence was not known, but there were many evidences that possibly a third of preterm delivery correlated with chorioamnionitis. But not all chorioamnionitis manifests clinically, and even so, it is believed that subclinical chorioamnionitis is enough to elicit prostaglandin production which plays a major role in initiating delivery. ${ }^{1}$

The cause of preterm delivery is usually can nor be determined. There are several concepts trying to explain the cause of preterm delivery are always associated with infection of amniotic fluid, uteroplacental ischemia, overdistended uterus, endocrinology abnormalities and abnormal immune response wether from the mother or the fetus. ${ }^{5}$

Preterm delivery could also caused by malnutrition, alcohol consumption, exposure to cigarette smoke, infection, multiple pregnancies, abnormal coagulation, premature rupture of membrane, and abruption of placenta. The most likely condition is an inflammation process mediated by pro-inflammation cytokine causing premature delivery. ${ }^{6}$ The evidence that the occurence of delivery is the result of inflammation process could be observed by the increasing proinflammation agents in myometrium, cervix, fetal membrane, and peripheral circulation when delivery happens. This is also coincide with inflammation as the result of infection in preterm delivery. ${ }^{7}$

Considering those fact, we need an early intervention in prevention and management of preterm delivery. It is important to have an understanding regarding etiology and mechanism of preterm delivery to identify diagnostic markers and develop medicine act specifically on a safe and efficient uterus contraction. ${ }^{8}$
Delivery process is associated with proinflammatory mediator (TNF- $\alpha$, IL-1 $\beta$, IL-6, IL-8, MCP-1, ect.) in the gestational tissue, thus theoretically a rational intervention is anti-inflammatory drug. In this case, IL-10 is an anti inflammation cytokine which is produced by trophoblastic tissue, desidua and human chorion. The decreasing basal production of IL-10 caused the initiation of inflammatory process. ${ }^{9}$ Data also showed that the intravenous injection of IL-10 in mice given endotoxin previously could prevent preterm delivery. ${ }^{10}$ Pomin et al also found similar result that the production of proinflammatory mediator could be prevented by giving IL-10.11 But other research showed that IL-10 could also play a role in increasing inflammatory process in the inner gestational membrane. ${ }^{12}$

Considering these data, we were interested in conducting this research to find out whether there is a difference of IL-10 level in women experiencing preterm delivery compared to a term delivery. We believed the result could be use as additional information in the management of preterm delivery.

\section{METHOD}

This research was a cross sectional study. It was conducted in the Obstetrics and Gynecology Department in several educational hospital of Faculty of Medicine, Hasanudin University, Makassar. This study was performed from August 2011 until the sampel was adequate. The subject was all pregnant women with preterm delivery fulfilling the inclusion criteria.

\section{RESULT}

The number of subject was 48 women, 12 of which was in the aterm group and 35 was in the preterm group. The mean age of the subject was $37.3 \pm 4.37$. The full characteristic of the subject was described in Table 1.

The men level of IL-10 in this study was $30.36 \pm 10.65 \mathrm{pg} / \mathrm{ml}$. The mean level in the preterm group was $41.92 \pm 12.52$, meanwhile in the aterm grup, the mean level of IL-10 was $26.21 \pm 6.49$. The result is completely described in Table 2 . We found that there was a significant difference of the IL-10 level in both groups $(\mathrm{p}<0.001)$. 
Table 1. Subject characteristic

\begin{tabular}{llrc}
\hline \hline \multicolumn{1}{c}{ Variable } & \multicolumn{1}{c}{ Category } & n (n=48) & \% \\
\hline Group & Preterm & 12 & 25 \\
& Aterm & 36 & 75 \\
Parity & 0 & 8 & 16.7 \\
& 1 & 21 & 43.8 \\
& 2 & 11 & 22.9 \\
& 3 & 5 & 10.4 \\
& 4 & 2 & 4.2 \\
& 5 & 1 & 2.1 \\
Education & Elementary school & 8 & 16.7 \\
& Junior high school & 19 & 39.6 \\
& Senior high school & 21 & 43.8 \\
Prior history & No & 40 & 83.3 \\
of abortion & Yes & 8 & 16.7 \\
\hline \hline
\end{tabular}

Table 2. Bivariate analysis of IL-10 level

\begin{tabular}{llll}
\hline \hline \multicolumn{1}{c}{ Variable } & Category & IL-10 level & p value \\
\hline Gestational age & Preterm & $41.92 \pm 12.52$ & $<0.001^{*}$ \\
& Aterm & $26.21 \pm 6.49$ & \\
Parity & $>2$ & $29.33 \pm 6.11$ & $0.78^{*}$ \\
& $0-2$ & $30.57 \pm 11.39$ & \\
High-risk age & Yes & $36.39 \pm 9.44$ & $0.015^{*}$ \\
& No & $28.56 \pm 10.44$ & \\
$\begin{array}{l}\text { Prior history } \\
\text { of abortion }\end{array}$ & No & $29.67 \pm 10.84$ & $0.174^{*}$ \\
\hline \hline
\end{tabular}

*Mann Whitney

The mean level of IL-10 in aterm group (was $30.36 \pm 10.65 \mathrm{pg} / \mathrm{ml}$ ) was similar with the level achieved in previous study, which performed on women with normal pregnancy on third trimester $(33.8 \pm 3.8) \cdot{ }^{13}$

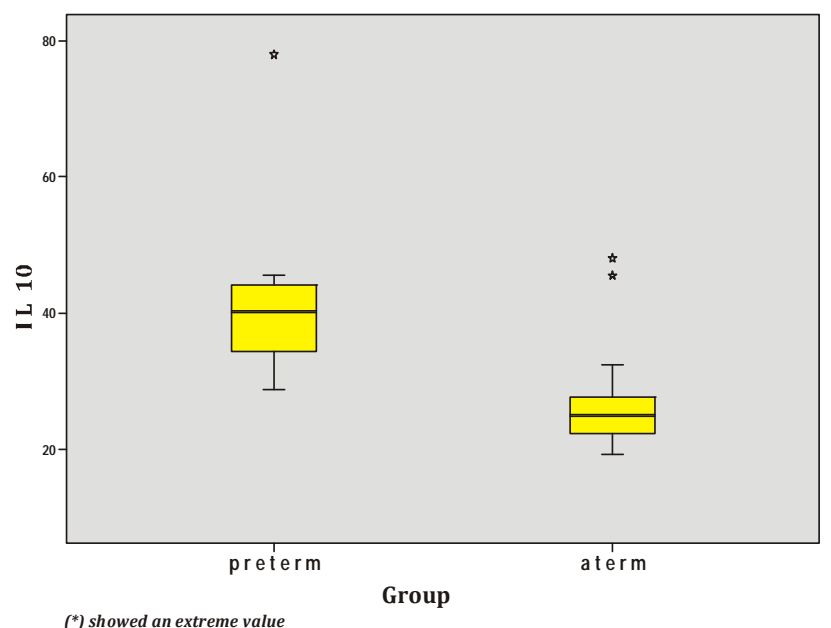

Figure 1. IL-10 level according to aterm or preterm group.
There was a significant difference of IL-10 level between the preterm and aterm delivery group, where as the level was higher in the cervic of women with preterm delivery. We also found that the level was significantly higher in the cervix of women of a high risk age. Meanwhile, parity and prior history of abortion showed no significant difference of IL-10 level in both groups.

This result is consistent with previous study performed by Dubicke et al which showed an mRNA expression and protein from IL-10 which was higher in the cervix of women with preterm delivery. This showed that there is a disregulation of anti-inflammatory cytokine as a result of a pathological condition in the cervix. The pro-inflammatory cytokine will rise thus induce the procution of anti-inflammatory cytokine, especially IL-10 to maintain pregnancy by preventing the softening and dilatation of cervix.

From this study, we could conclude a theory that cervical insufficiency and preterm delivery is marked by inflammation, in which there was a rise of inflammatory cytokine, the imbalance of proinflammatory and anti-inflammatory cytokine could cause preterm delivery.

This study also showed that measuring the concentration of cytokine in the cervix throughout pregnancy could be applied and also important in order to understand and monitor the inflammation condition in pregnancy. In other words, IL-10 level could be used as a marker or a predictor in pathological condition, thus could also predict the outcome of delivery or to screen the risk for preterm delivery.

It is interesting to find that the IL-10 in the group with high risk age was higher than the lowrisk age group. This showed that high risk age group has a pathological condition which could enable inflammation causing premature delivery, or any other pathological condition.

Unfortunately, in this study, we only measured the anti-inflammatory cytokine. It is recommended to perform a further research measuring proinflammatory cytokine in order to measure the ratio between the pro and anti-inflammatory cytokine. Beside, in order to identify the role of IL-10 as the predictor of preterm delivery even further, research should be done in a prognostic or prospective manner. 
The other limitation of this research was the absence of microbiology examination to see whether there was an infetion or not in the pathologic process of preterm delivery. The pathological process of preterm delivery is strongly assicoated with inflamation, as mentioned before. Inflammation is one of the response towards cell injury caused by microorganism exposure. Inflammation and infection appeared to be the most important in preterm delivery. ${ }^{14,15}$ Research performed by Gupea found that non-lactobacillus was the most commonly detected organism from the cervical fluid (25\%) and the presence of Ureaplasma urealyticum is strongly associated with the rise of IL-6 level in the cervix of women undergoing preterm delivery. Thus, future research should perform microorganism examination. But in this research, the presence of infection is presumed to be none because we recruited patients with normal level of leucocyte.

\section{CONCLUSION}

The level of IL-10 in the cervix of women with preterm delivery is higher than in women with aterm delivery. The measurement of IL-10 level as an antiinflammation cytokine could be performed in the sample acquired from cervix, instead of the more difficult source such as the placenta or amniotic fluid. This showed that IL-10 level could be used as a predictor for the occurrence of preterm deliveries or other pathologic condition in pregnancy.

\section{REFERENCES}

1. Suardana K, Kusuma A, Suwiyoga K, Susraini. Korioamnionitis Histopatologik sebagai Risiko Persalinan Preterm di RS Sanglah Denpasar. Cermin Dunia Kedokteran, 2004; 145: 17-20.

2. Challis J, Sloboda D, Alfaidy N, Lye S, Gibb W, Patell FA, Whittle WL, JP, N. Prostaglandins and mechanisms of preterm birth. 2002; 124: 1-17.
3. Hamid R, R D.S. Analisis faktor resiko persalinan prematur dan hubungannya dengan cara persalinan dan hasil luaran bayi di RSUP Dr Wahidin Sudirohusodo Makassar, Periode 2007-2010. PIT POGI XX, Jakarta. 2011.

4. Romero R, Chaiworaponga M. Preterm Labour. Intrauterine Infection and the Fetal Inflammatory Response Syndrome. Perin Res Bran, 2002; 3: 74-85.

5. Lockwood CJ, Arcuri F, Toti P, et all. Tumor Necrosis Factor-alpha and Interleukin-1 B Regulate Interleukin-8 Expression in Third Trimester Decidual Cells. Am J Pathol. 2006; 169: 1294-1301.

6. Peltier MR. Immunology of Term And Preterm Labor. BMC Reproductive Biology \& endocrinology, 2003; 1.

7. Norman JE, Bollapragada S, Yuan M, et all. Inflamatory Pathways In The Mechanism of Parturition. BMC Pregnancy and Childbirth, 2007; 7: 1-4.

8. Bernalu AL. Overview. Preterm labour: Mechanism and management. BMC Pregnancy and Childbirth, 2007; 7 (Supp. I).

9. Simpson KL, Keelan JA, Mitchell MD. Labor-Associated Changes in Interleukin-10 Production and Its Regulation by Immunomodulators in Human Choriodecidua. J Of Clin Endocrinology and metabolism, 2007; 83(12): 4332-7.

10. Terron DA. Interleukin-10 Administration and bacterial Endotoxin-Induced Preterm Birth in a Rat Model. Am College Obset Gynecol. 2001; 98(3): 476-80.

11. Pomini F, Caruso A, Challis JRG. Interleukin-10 Modifies the Effects of Interleukin-1b and Tumor Necrosis Factor-a on the Activity and Expression of Prostaglandin H Synthase-2 and the NAD1 Dependent 15-Hydroxyprostaglandin Dehydrogenase in Cultured Term Human Villous Trophoblast and Chorion Trophoblast Cell. J Clin Endocrin Metabolism, 2007; 84(12): 4645-50.

12. Mitchell MD, Simpson KL, Keelan JA. Paradoxical Proinflammatory Actions Of Interleukin-10 In Human Amnion: Potential Roles In Term And Preterm Labour. J Clin Endocrinol Metabolism. 89(8), 4149-52.

13. Mondestin-Sorrentino M, Smulian JC, Vintzileos AM, et al. Variations in Cervical IL-10 and IL-8 Concentrations Throughout Gestation in Normal Pregnancies. Am J Reprod Immunol. 2007; 57: 482-7.

14. Gibbs RS, Romero R, Hillier SL, et all. A review of premature birth and subclinical infection. Am J Obstet Gynecol. 1992; 166(5): 1515-28.

15. Goldenberg RL, Hauth JC, Andrews WW. Intrauterine infection and preterm delivery. N Engl J Med, 2000; 18;342.20: 1500-7. 